\title{
Numerical simulation of a rare winter hailstorm event over Delhi, India on 17 January 2013
}

\author{
A. Chevuturi ${ }^{1}$, A. P. Dimri ${ }^{1}$, and U. B. Gunturu ${ }^{2}$ \\ ${ }^{1}$ School of Environmental Sciences, Jawaharlal Nehru University, New Delhi, India \\ ${ }^{2}$ King Abdullah University of Science and Technology, Thuwal, Saudi Arabia \\ Correspondence to: A. P. Dimri (apdimri@hotmail.com)
}

Received: 6 August 2014 - Published in Nat. Hazards Earth Syst. Sci. Discuss.: 24 September 2014

Revised: - - Accepted: 21 November 2014 - Published: 19 December 2014

\begin{abstract}
This study analyzes the cause of the rare occurrence of a winter hailstorm over New Delhi/NCR (National Capital Region), India. The absence of increased surface temperature or low level of moisture incursion during winter cannot generate the deep convection required for sustaining a hailstorm. Consequently, NCR shows very few cases of hailstorms in the months of December-January-February, making the winter hail formation a question of interest. For this study, a recent winter hailstorm event on 17 January 2013 (16:00-18:00 UTC) occurring over NCR is investigated. The storm is simulated using the Weather Research and Forecasting (WRF) model with the Goddard Cumulus Ensemble (GCE) microphysics scheme with two different options: hail and graupel. The aim of the study is to understand and describe the cause of hailstorm event during over NCR with a comparative analysis of the two options of GCE microphysics. Upon evaluating the model simulations, it is observed that the hail option shows a more similar precipitation intensity with the Tropical Rainfall Measuring Mission (TRMM) observation than the graupel option does, and it is able to simulate hail precipitation. Using the modelsimulated output with the hail option; detailed investigation on understanding the dynamics of hailstorm is performed. The analysis based on a numerical simulation suggests that the deep instability in the atmospheric column led to the formation of hailstones as the cloud formation reached up to the glaciated zone promoting ice nucleation. In winters, such instability conditions rarely form due to low level available potential energy and moisture incursion along with upper level baroclinic instability due to the presence of a western disturbance (WD). Such rare positioning is found to be lowering
\end{abstract}

the tropopause with increased temperature gradient, leading to winter hailstorm formation.

\section{Introduction}

An unusual winter hailstorm occurred over National Capital Region (NCR)/New Delhi, India on 17 January 2013 (16:00 18:00 UTC). Figure 1 shows satellite image of extensive cloud cover over the northern Indian region during this time. Heavy precipitation was observed over the northern Indian region including some parts of the western Himalayas. In NCR and surrounding regions, there was freak incidence of hail as well as severe rainfall. Table 1 corresponds to the summary of hailstorm cases over NCR (NNDC-CDO, 2013). Primarily, the Indian climate is divided into four seasons; premonsoon (March-April-May), monsoon (June-July-AugustSeptember), post-monsoon (October-November) and winter (December-January-February) (Attri and Tyagi, 2010). With such a classification, a pattern is observed, where most hailstorms cases over NCR dominate during the warmer periods of pre-monsoon and monsoon months. It is seen that no hailstorm cases occurred during months of February and October whereas a very few hailstorm cases occur during the winter months. Out of the 33 hailstorm cases, only 5 occur during the colder/winter period (with January showing only 2 cases). Thus, winter hailstorms can be considered a rare occurrence over NCR. With such a distinction between summer and winter hailstorms, it can be hypothesized that the mechanisms of these two kinds of hailstorms are different, which are deliberated in the following paragraphs.

Over the northern Indian region, pre-monsoon storm events occur during convectively unstable atmospheric 


\begin{tabular}{|c|c|c|c|}
\hline 17JAN2013 1800 UTC & Sensor: VHR & SAT : KALPANA-1 & \\
\hline ASIA_MER & Proj : MERCATOR & Resolution : $8000 \mathrm{~m}$ & \\
\hline
\end{tabular}

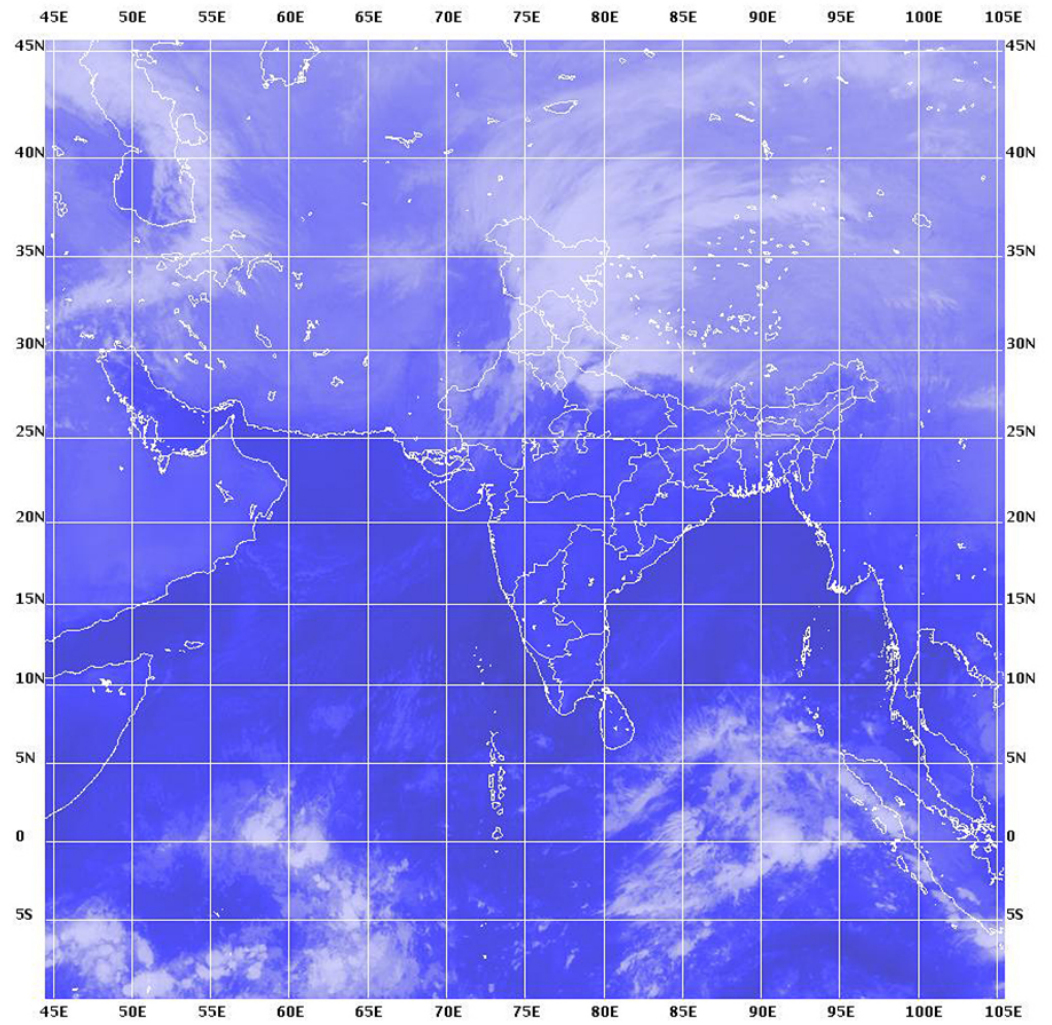

Figure 1. Kalpana-I satellite image for 18:00 UTC 17 January 2013 with a Very High Resolution (VHR) sensor over Asia with Mercator projection (Source: http://www.imd.gov.in/section/satmet/dynamic/insat.htm).

conditions culminating due to transient disturbances observed in the air mass due to the surface heating. Storms may be categorized as severe storms if they are associated with hail, thunder, lightning, high winds, etc. (Houze Jr., 1981). These severe storms occur during strong vertical wind shear, which are ideal conditions for hail formation (Orville and Kopp, 1977). During the monsoon, the precipitation is caused due to the development of deep convection because of higher surface temperature and vertical wind shear of southwesterly flow and associated moisture incursion over the Indian subcontinent. The convective precipitation is also facilitated by surface terrain and the Himalayan orography. These periods of precipitation occurrences during the monsoon are associated with rainfall and in extreme cases hail (Koteswaram, 1958; Ramage, 1971; Sikka, 1977; Lau et al., 2012). In the context of hailstorms, it can be concluded that convection due to high surface temperatures and moisture laden flow are important for hailstorm formation. Hail is precipitation in the form of hard, rounded pellets of irregular lumps of ice. In cross section, hail shows concentric shells of different densi- ties and degrees of opaqueness (Pruppacher and Klett, 2010). These multiple layers of ice within hail are formed due to continuous deposition and shedding of ice over the condensation nuclei as the hailstones cycle through strong convective clouds having multiple updrafts and downdrafts (Chatterjee et al., 2008).

The winter months are associated with absence of increased surface temperatures or low level of moisture incursion, making it a cold and dry season (Attri and Tyagi, 2010). These conditions are not conducive for generation of the deep convection required for sustaining a hailstorm. In the month of January, the average temperature of Delhi is $13.5^{\circ} \mathrm{C}$ (NNDC-CDO, 2013). With such a low mean temperature, it is difficult for a storm to attain the wind shear required for hail formation. Studying such unusual/abnormal meteorological condition conducive for winter hail formation is of interest. Thus, this study has a new and unique perspective for understanding the dynamics of a winter hailstorm occurrence. Though hailstorms are a rare phenomenon due to very specific conditions of formation and subsequent 
Table 1. Cases of the hailstorms over NCR from 1943-2013 (NNDC-CDO, 2013). The case discussed in the present study is marked with *.

\begin{tabular}{|c|c|c|}
\hline Months & Cases & Dates \\
\hline January & 2 & 2012-01-06, 2013-01-17* \\
\hline February & 0 & - \\
\hline March & 4 & $\begin{array}{l}1957-03-30,1974-03-11 \\
1975-03-24,2013-03-28\end{array}$ \\
\hline April & 7 & $\begin{array}{l}\text { 1944-04-03, 1957-04-15, } \\
\text { 1978-04-18, 1983-04-16, } \\
\text { 1991-04-22, 1993-04-10, 2004-04-22 }\end{array}$ \\
\hline May & 5 & $\begin{array}{l}1958-05-30,1983-05-18, \\
1994-05-05,1994-05-09,1996-05-11\end{array}$ \\
\hline June & 3 & $2000-06-04,2000-06-24,2004-06-23$ \\
\hline July & 2 & $2000-07-16,2000-07-24$ \\
\hline August & 5 & $\begin{array}{l}1986-08-31,2005-08-20 \\
2006-08-14,2009-08-25,2011-08-04\end{array}$ \\
\hline September & 2 & $1975-09-20,1984-09-12$ \\
\hline October & 0 & - \\
\hline November & 1 & $1973-11-10$ \\
\hline December & 2 & $1977-12-23,1990-12-29$ \\
\hline Total & 33 & \\
\hline
\end{tabular}

occurrence (Table 1), they are quite hazardous. Hailstones destroy crop, infrastructure, property and in extreme cases may cause injuries to humans (De et al., 2005). Due to the perspective of hailstorms happening only in summer, hailstorms are not expected in the winter months. This may lead to unpreparedness in early warning systems for hail prediction and mitigation of damage due to hailstorms, which may lead to devastating consequences.

Numerical weather prediction technique is utilized for understanding the above discussed storm event. This storm is simulated with the Weather Research and Forecasting (WRF) model with Advanced Research WRF (ARW) dynamical core. As hail formation is a microphysical process, the study mainly focuses on the use of the Goddard Cumulus Ensemble (GCE) (Lin et al., 1983; Rutledge and Hobbs, 1984; Tao and Simpson, 1993) microphysics scheme to simulate hail formation. This scheme simulates six different hydrometeors or water particles: water vapor (WV), cloud water (CW), cloud ice (CI), rainwater (RW), snow, and a third class of ice. The third class of ice can be graupel or hail as per the options used during simulation. Graupel is relatively smaller and less dense hydrometeor ice particle when compared with hail. These variations cause differences in microphysical properties of the model parameterization. This study includes analysis of simulations with both options of GCE microphysics for the hailstorm event, which will hereafter be referred to as the hail option and the graupel option.

With these considerations, the objectives of this study are listed below.

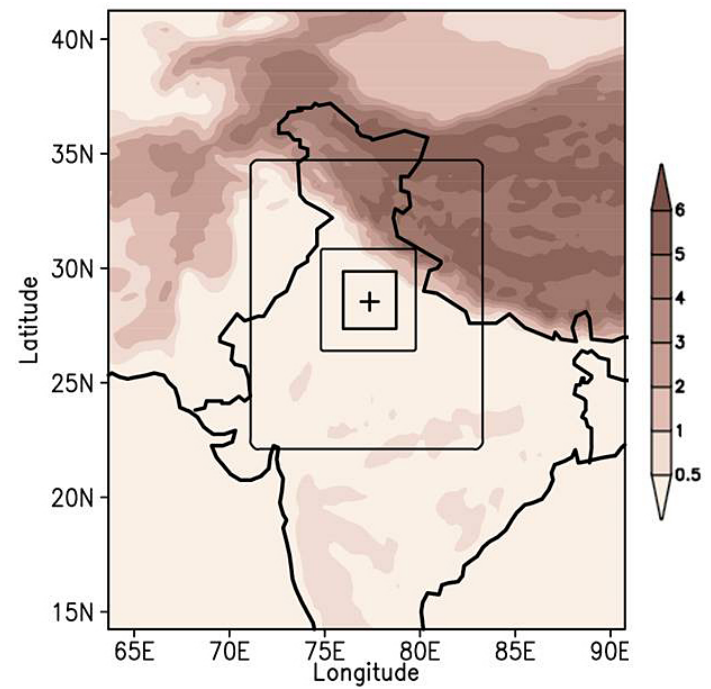

Figure 2. Model domain and topography $\left(\times 10^{3} \mathrm{~m}\right.$; shaded). The shaded region corresponds to model domain $1(27 \mathrm{~km}$ horizontal model resolution), and boxes with solid black lines indicate model domain 2 (9 km horizontal model resolution), domain 3 (3 km horizontal model resolution), and domain 4 ( $1 \mathrm{~km}$ resolution). The plus sign indicates the location of NCR.

- To understand and describe a winter hailstorm event over NCR, with discussion on the large-scale flow and precipitation associated during such storms.

- To simulate the hailstorm event using the GCE microphysics scheme's hail and graupel options for a comparative analysis in the two options.

- To study in detail the various thermodynamic and microphysical processes associated with the hailstorm formation using the GCE microphysics with hail option.

This paper is divided into the following sections with Sect. 2 describing experimental design and data, Sect. 3 showing results and discussion and summary and conclusion provided in Sect. 4.

\section{Experimental design and data}

In this study, the WRF model (version 3.0) with the ARW dynamic solver is used to simulate the hailstorm event. The WRF model is a mesoscale dynamical model, developed by a multi-institutional collaboration (Wang et al., 2010) including the National Oceanic and Atmospheric Administration (NOAA), USA and the National Center for Atmospheric Research (NCAR), USA. The ARW dynamic solver (Skamarock et al., 2008) is developed primarily at NCAR. The model domain is set up over India with a central domain point at $\mathrm{NCR}\left(28.6^{\circ} \mathrm{N}, 77.2^{\circ} \mathrm{E}\right)$, where the high intensity precipitation was reported, with four nests of 27, 9,3 and 
Table 2. Description of model details.

\begin{tabular}{ll}
\hline Model & WRF Version 3.0 \\
Map projection & Mercator \\
Horizontal resolution & Nest: 27, 9, 3, and 1 km \\
Hailstorm case simulation & $00: 00$ UTC 16 January-00:00 UTC 19 January 2013 \\
Central point of domain & $28.6^{\circ} \mathrm{N}, 77.2^{\circ} \mathrm{E}$ \\
Horizontal grid scheme & Arakawa C-grid \\
Time step & $162 \mathrm{~s}$ \\
Microphysics & GCE scheme (with hail option and graupel option) \\
Land surface model & Noah Land Surface Model \\
Surface layer model & MM5 Similarity Model \\
Radiation scheme & Shortwave - Dudhia scheme; Longwave - RRTM scheme \\
Planetary boundary layer & Mellor-Yamada-Janjic scheme \\
Cumulus parameterization & Kain-Fritsch scheme \\
\hline
\end{tabular}

RRTM - Rapid Radiative Transfer Model

$1 \mathrm{~km}$, respectively (Fig. 2 and Table 2). Model simulations are analyzed for $72 \mathrm{~h}$ starting from 00:00 UTC 16 January 2013, to understand the meteorological processes contributing to the storm development and propagation. In the current study, not only model performance in simulating the precipitation event is evaluated for verification, but the large-scale atmospheric processes leading to the weather event are also analyzed. With such an aim, a 3-day simulation is deemed necessary for the study.

NCEP final analysis data (FNL), at $1^{\circ} \times 1^{\circ}$ spatial resolution, is used as the initial and lateral boundary conditions for the study (NCEP/NOAA/US-DoC, 2000). Initial conditions for the model are extracted from the FNL data set and are interpolated to the model domain. NASA's ModernEra Retrospective analysis for Research and Applications (MERRA) (Rienecker et al., 2011) 6-hourly analysis data set with a spatial resolution of $0.5^{\circ} \times 0.7^{\circ}$ is used as corresponding observational data. The Tropical Rainfall Measuring Mission (TRMM) multi-satellite precipitation analysis (real time data) 3B42 V7 (Huffman et al., 2007) at $0.25^{\circ} \times 0.25^{\circ}$ spatial resolution is used as the observation for the precipitation fields. The daily Outgoing Longwave Radiation (OLR; Liebmann and Smith, 1996) data set provided by Earth Systems Research Laboratory (ESRL), National Oceanic and Atmospheric Administration (NOAA), USA, available at $2.5^{\circ} \times 2.5^{\circ}$ spatial resolution is used for validation purposes.

As discussed previously, the GCE microphysics scheme (Tao and Simpson, 1993) is used in the model simulation experiments. This parameterization scheme is based on the multi-dimensional, non-hydrostatic microphysics cloud resolving model (Simpson and Tao, 1993). The microphysics scheme simulates six different hydrometeors: WV, CW, CI, RW, snow and the third class of ice (which can be either hail or graupel, as specified). The two options are different due to different microphysical processes considered for hail/graupel formation, which in turn impact the hydrometeor population.
As both the hydrometeors are quite alike, their formation processes considered in both options of the parameterization scheme are similar; accretion of RW, aggregation of snow, rimming of CI, sublimation and melting (Lin et al., 1983). But with graupel option, two other processes are included for graupel formation; autoconversion of snow and deposition of WV (Rutledge and Hobbs, 1984). In this study to understand the microphysical process of hail formation and its complexities, two comparative simulations are conducted using the hail and graupel options specifically. It is to be mentioned that in both simulations 3 and $1 \mathrm{~km}$ resolution nests were simulated with explicit representation of cumulus parameterization scheme. As model for simulations at horizontal resolutions smaller than $3 \mathrm{~km}$, estimates the precipitation by the cloud microphysics scheme itself (Gomes and Chou, 2010).

\section{Results and discussion}

\subsection{Analysis of large scale flow and precipitation}

The model-simulated large scale flow patterns at $500 \mathrm{hPa}$ and its corresponding MERRA observation is depicted in Fig. 3. The large-scale circulation showed a deep trough being formed over the region comprising of western Indian and Pakistan in model fields and corresponding MERRA observational analysis. Figure 3 depicts that both the model simulations capture the wind and geopotential height patterns with slight over estimation. The depression observed over the region corresponds to an incoming western disturbance (WD). WDs are eastward-moving synoptic scale extra-tropical cyclonic systems in the sub-tropical westerly jet. These originate in the Mediterranean Sea and cause precipitation over northern India mainly during the months of December-January-February due to their interaction with the Himalayan orography (Dimri, 2004). This migratory disturbance in the mid-troposphere along with the stationary 
surface low over western India is called the WD, and generates the instability necessary for winter precipitation (Dimri and Chevuturi, 2014). The presence of this system can be the cause for the enhanced the instability over the region that influences the storm formation.

Daily mean outgoing longwave radiation (OLR) for 17 January 2013 is depicted in Fig. 4 for model simulations and corresponding observation. A clear region of low OLR values is seen over whole of northern India including the NCR in both model options and observations. OLR can be considered as an indicator to describe the clouding condition or precipitation globally (Xie and Arkin, 1998). In the presence of increased extent and depth of cloud cover and lower cloud top temperatures in high clouds, low OLR values are recorded. Thus, the figure represents the cloud extent during the time period of the hailstorm. Upon evaluating the satellite image of Fig. 1, similar cloud extent is observed over the same region. The low values of OLR over the whole of northern Indian region depict extensive cloud cover and the possibility of precipitation over the region. The advance of WDs and interaction with the Himalayas is associated with the development of mesoscale cloud formation (Puranik and Karekar, 2009) as seen during this event. Moisture flux transport and divergence integrated over the vertical atmospheric column (Howarth, 1983) for observation and model simulations is shown in Fig. 5. In model-simulated outputs, a strong region of moisture convergence is seen over NCR and some parts of the Himalayan region north of NCR. Corresponding observations show a similar extent of moisture convergence zone, but the strength of moisture convergence is lower. According to the figure, it is observed that the Arabian Sea and the Bay of Bengal are both sources of moisture for the convergence zone. The moisture laden flow from these sources flows over the Indian subcontinent, congregates and flows towards NCR. This moisture is important for the maintenance of the winter storm over northern India and its role will be discussed later in detail.

Analysis of 3-hourly precipitation rates from model simulations and their corresponding observations are shown in Fig. 6. The figure suggests that there was a storm having maximum intensity over NCR between 15:00 to 18:00 UTC of 17 January 2013. This storm showed a localized formation over NCR and its surrounding region. When compared with the observation, model-simulated output shows a similar spatial extent of precipitation patterns. The axis of the storm evolution is observed to be oriented along the northeast to southwest direction. Upon evaluating the two model simulations, it is observed that the hail option shows closer precipitation intensity with the TRMM observation than the graupel option. The spatial extent of the precipitation pattern observed in the hail option is also a better match when compared with the observational analysis. Figure 6 also depicts that storm cluster moves eastward as the storm progresses. The analysis shows a localized cluster of storm that is the cause of the heavy precipitation event. But when the point specific precipitation intensity at NCR is compared between the different options, overestimation is observed in model simulation. Inter-comparison in temporal variation in halfhourly precipitation intensities of both model simulations is shown in Fig. 7 for all four horizontal model resolutions. The figure suggests peak concentration of precipitation around NCR was observed around 17:00 UTC on 17 January 2013. Here it is also clearly noted that hail option shows higher precipitation estimates than the graupel option. Deliberations on reasons for variation in precipitation intensities within the options of microphysics are provided in next section by comparative analyses of the flux in the different hydrometeors in different options.

\subsection{Comparative analysis between hail and graupel options of GCE microphysics}

Figure 8 depicts the mixing ratios of different hail and graupel outputs over spatial and temporal scales for both hail and graupel options with zonal and vertical wind vectors. Increased concentrations of mixing ratios of all six hydrometeors are observed over the NCR around the peak of the storm (Figs. S1-S5 in the Supplement). These hydrometeors are indicators of cloud formation over the region. All the hydrometeor mixing ratio concentrations show higher values over NCR around 16:30 UTC, which is just before storm peaks representing storm evolution and/or buildup. In hail option, the increased formations of hydrometeors are specifically observed over NCR, whereas some displacement is seen in graupel option output. In addition, the spatiotemporal variation of these mixing ratios shows an eastward movement of the storm. The wind movement in Fig. 8a shows upward motion of wind in front of the hail hydrometeors mixing ratio peak, this updraft ascent from surface in the opposite direction of storm movement is a typical characteristic of hailstorm formation (Chalon et al., 1976), which is not observed in graupel option (Fig. 8d). The increase of WV is due to the moisture incursion from the Arabian Sea and the Bay of Bengal. Condensation and deposition processes lead to the formation of $\mathrm{CW}$ and CI from WV due to decreasing temperatures, forming the clouds. The RW droplets formation is enhanced by the processes of collision and coalescence (Orville and Kopp, 1977), and ultimately sediment out as rain. Increased RW mixing ratios are an indicator of increased precipitable water availability in the atmospheric column. With the development of stronger storm conditions, there is formation of other hydrometeors like snow, hail and graupel. With the main focus of the paper on the third class of ice, we will be discussing hail and graupel in more detail.

Hail and graupel are both ice particles seen during storm formation. Hail is an ice particle which is formed due to consecutive processes like soft hail processes (dry growth and raindrop freezing) or hard hail processes (wet growth and shedding) (Wisner et al., 1972). These continuous and repeated processes form a differentially layered ice 

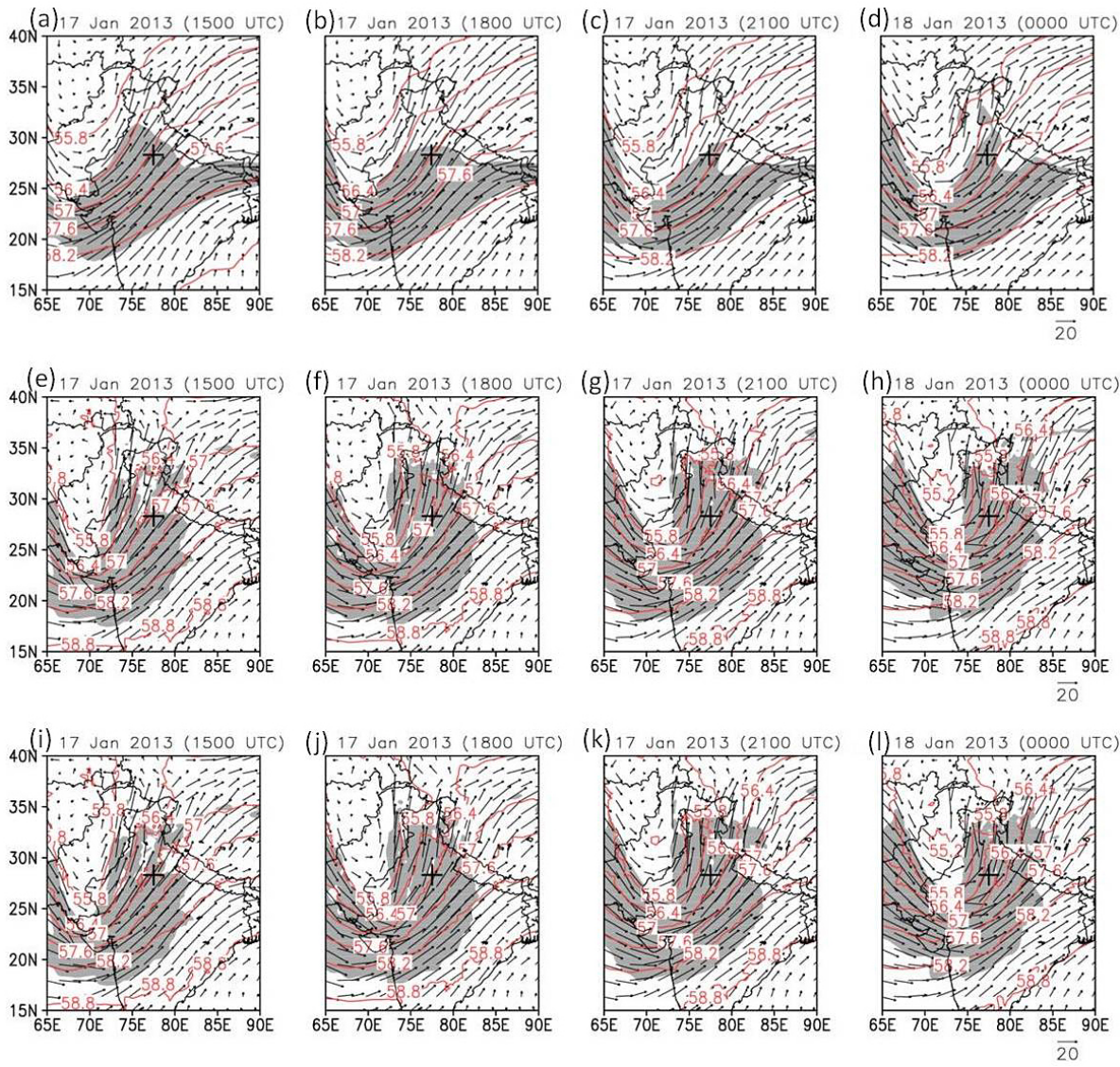

Figure 3. $500 \mathrm{hPa}$ wind $\left(\mathrm{m} \mathrm{s}^{-1}\right.$; vector), geopotential height $\left(\mathrm{gpm} \times 100\right.$; contour) and wind speed ( $\mathrm{m} \mathrm{s}^{-1}$; greater than $25 \mathrm{~m} \mathrm{~s}{ }^{-1}$ shaded in grey) from 15:00 UTC 17 January-00:00 UTC 18 January 2013 at every $3 \mathrm{~h}$ for (a-d) MERRA data, (e-h) model output with hail option, and (i-l) model output with graupel option at $27 \mathrm{~km}$ horizontal model resolution. Plus sign denotes NCR.
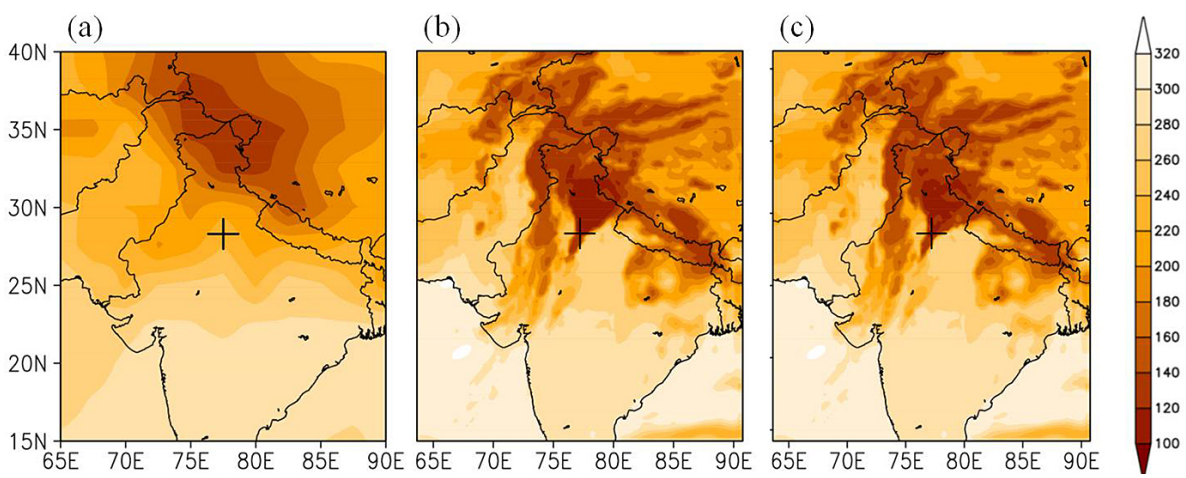

Figure 4. Daily mean OLR $\left(\mathrm{W} \mathrm{m}^{-2}\right)$ at 17 January 2013 for (a) NOAA data, (b) model output with hail option, and (c) model output with graupel option at $27 \mathrm{~km}$ horizontal model resolution. Plus sign denotes NCR.

precipitation type called hail (Pruppacher and Klett, 2010). The hailstones grow as the ice particles cycle through multiple cells of convective clouds (Chatterjee et al., 2008). Graupel are similar but smaller ice particles with a diameter less than $5 \mathrm{~mm}$, formed exclusively by soft hail processes (Pruppacher and Klett, 2010). In the model simulation peak hail mixing ratios are observed over NCR around 16:00-
16:30 UTC, whereas graupel mixing ratios maxima is seen east of NCR. In the vertical profile, hail mixing ratios span from $800-200 \mathrm{hPa}$ whereas graupel mixing ratios show extent from $750-300 \mathrm{hPa}$. It is interesting to note that when hail and graupel mixing ratios are compared, the hail mixing ratios are lower than graupel mixing ratios. But graupel precipitation (precipitation of ice particles in the form of graupel, 
(a)

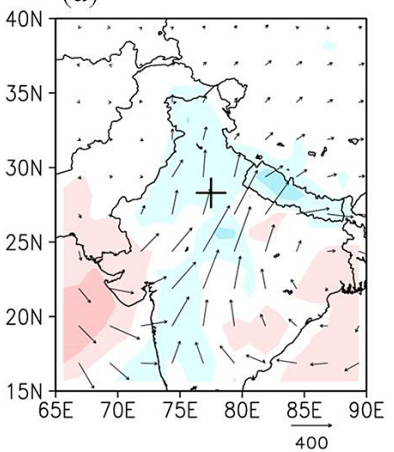

(b)

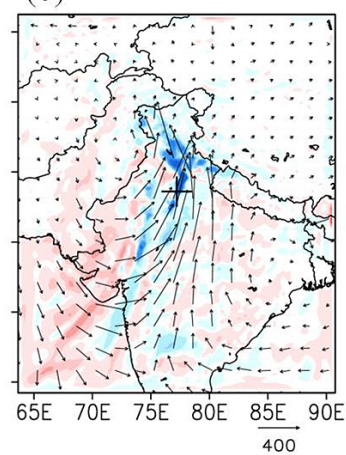

(c)

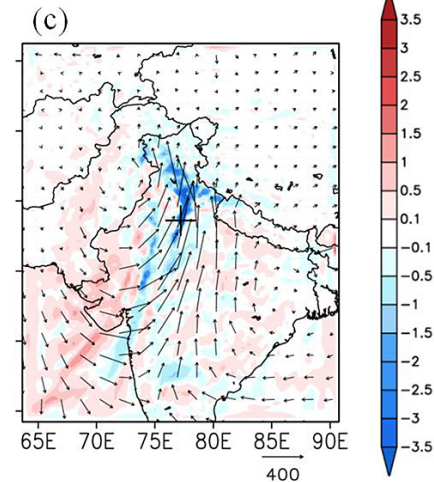

Figure 5. Vertical integrated moisture flux transport $\left(\mathrm{kg} \mathrm{m}^{-1} \mathrm{~s}^{-1}\right.$; vector $)$ and divergence $\left(\times 10^{-3} \mathrm{~mm}\right.$; shaded $)$ at 15:00 UTC $17 \mathrm{January}$ 2013 for (a) MERRA data, (b) model output with hail option, and (c) model output with graupel option at $27 \mathrm{~km}$ horizontal model resolution. Plus sign denotes NCR.

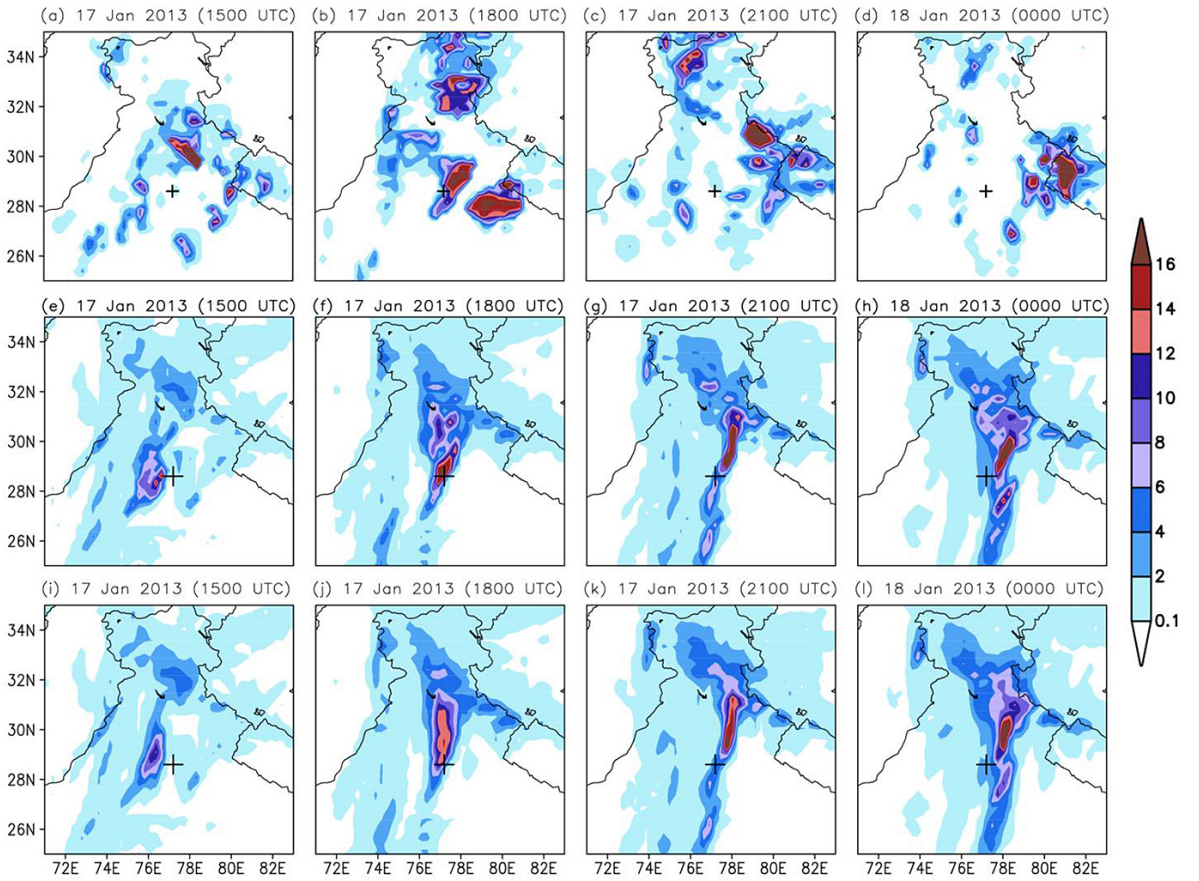

Figure 6. Precipitation $\left(\mathrm{mm} \mathrm{h}^{-1}\right)$ from 15:00 UTC 17 January to 00:00 UTC 18 January 2013 (a-d) TRMM data, (e-h) model output with hail option, and (i-l) model output with graupel option at $27 \mathrm{~km}$ horizontal model resolution. Plus sign denotes NCR.

which does not include liquid water precipitation) is not observed in the model simulation, but hail precipitation (same as graupel precipitation but with hail particles) is observed in the hail option around NCR between 16:30-17:00 UTC as shown in Fig. 9. This observation can be attributed to the fact that graupel have high number concentrations in the atmospheric column as these small ice particles are formed much quicker than hailstones. But due to their small size the graupel particles also melt quicker due to the temperature conditions that are not as low as seen over the snow line. Thus, precipitation of graupel is not observed over NCR but hail precipitation is seen during this hailstorm. With this discus- sion it can be concluded that to understand hail formation over NCR, microphysics with hail option needs to be studied in depth. Subsequent section focuses on understanding the cause of winter hailstorm formation.

\subsection{Detailed analysis of winter hailstorm formation}

For a focused analysis of the winter hailstorm formation the time period of peak precipitation 17:00 UTC 17 January 2013 represented at $1 \mathrm{~km}$ horizontal model resolution (Fiori et al., 2010) is considered (Fig. 10). Vertical cross sections of various parameters analyzed along the axis of core 

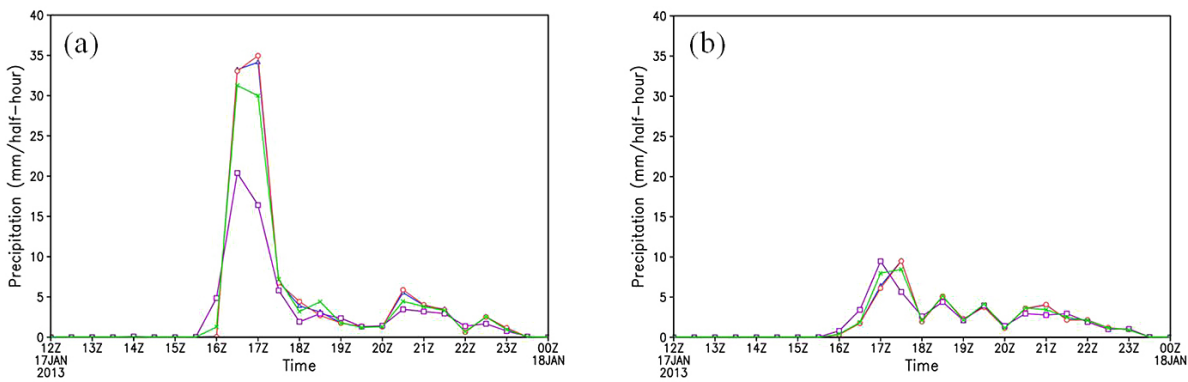

Figure 7. Precipitation (mm/0.5 h) from 00:00 UTC 17 January to 00:00 UTC 18 January 2013 at NCR for (a) model output with hail option and (b) model output with graupel option; with $27 \mathrm{~km}$ horizontal model resolution (purple line with squares), $9 \mathrm{~km}$ resolution (green line with cross), $3 \mathrm{~km}$ resolution (blue line with triangle) and $1 \mathrm{~km}$ resolution (red line with circle).
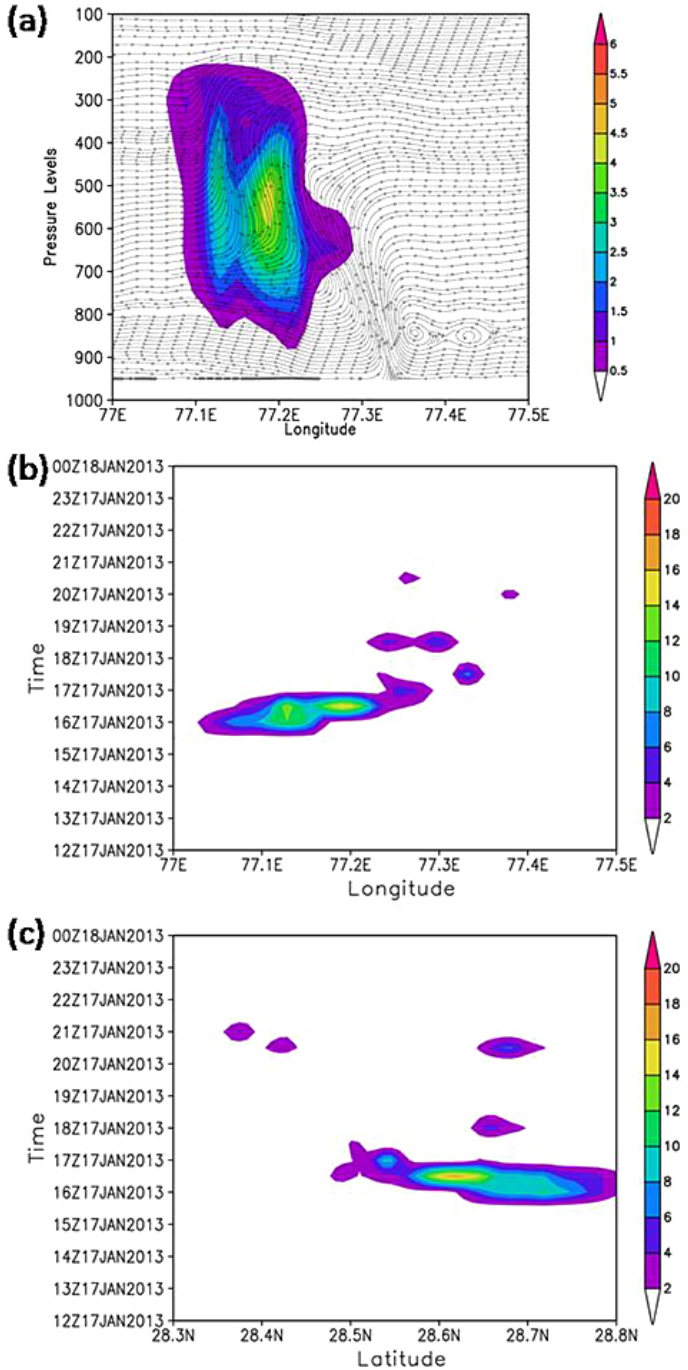

(d)
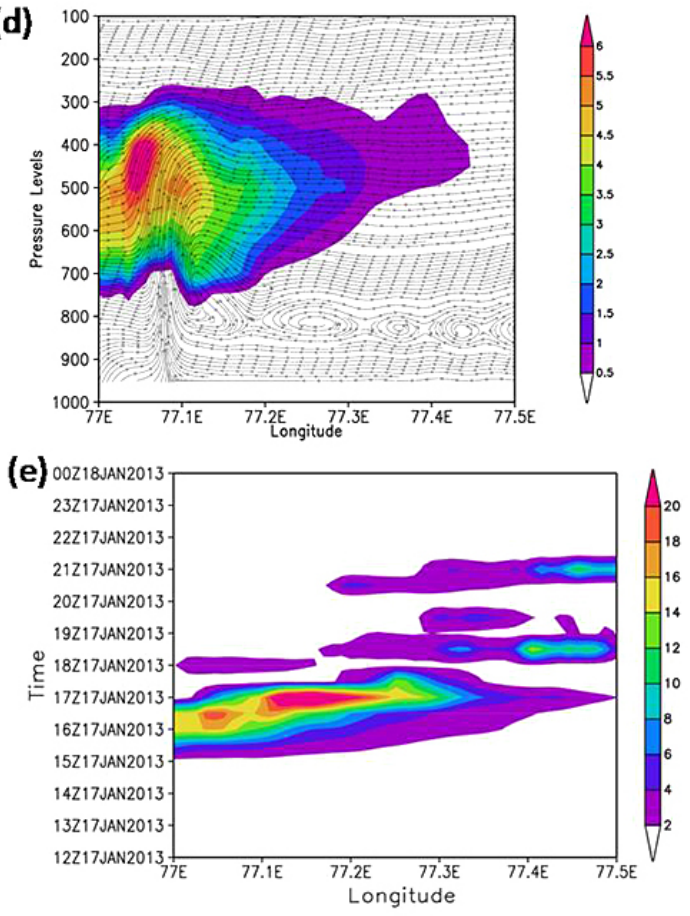

(f)

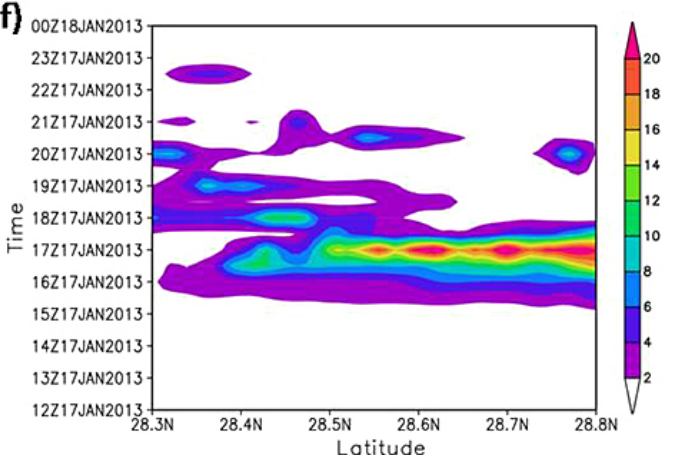

Figure 8. (a) Longitude-pressure cross section at latitude $28.6^{\circ} \mathrm{N}$ for model output at $1 \mathrm{~km}$ resolution at 16:00 UTC 17 January 2013 for hail mixing ratio $\left(\mathrm{g} \mathrm{kg}^{-1}\right.$; shaded) along with zonal and vertical wind ( $\mathrm{m} \mathrm{s}^{-1}$; vector) with hail option, (b) longitude time cross section for model output at $1 \mathrm{~km}$ resolution at 16:00 UTC 17 January 2013 for vertical integrated hail mixing ratio (kg kg ${ }^{-1}$; shaded) with hail option at latitude $28.6^{\circ} \mathrm{N}$, (c) latitude time cross section for model output at $1 \mathrm{~km}$ resolution at 16:00 UTC 17 January 2013 for vertical integrated hail mixing ratio $\left(\mathrm{kg} \mathrm{kg}^{-1}\right.$; shaded) with hail option at longitude $77.2^{\circ} \mathrm{E}$ and $(\mathbf{d}-\mathbf{f})$ same as (a-c) for graupel mixing ratio but with graupel option. 

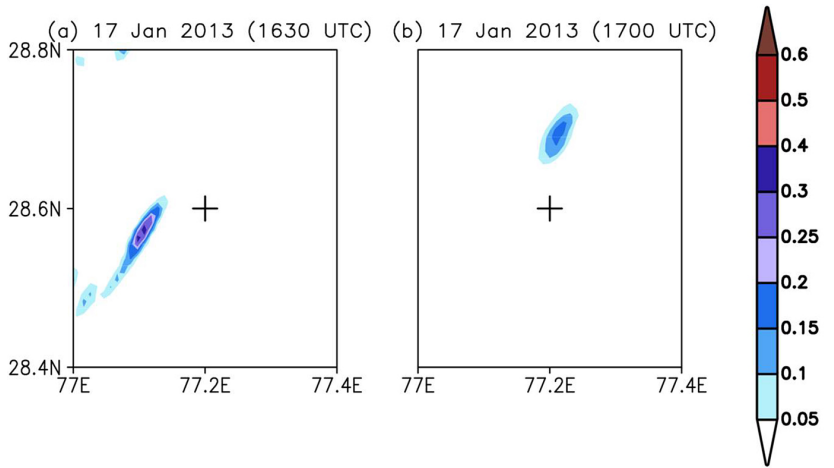

Figure 9. Hail precipitation $(\mathrm{mm} / 0.5 \mathrm{~h})$ at $27 \mathrm{~km}$ horizontal model resolution with hail option for (a) 16:30 UTC 17 January 2013 and (b) 17:00 UTC 17 January 2013. Plus sign denotes NCR.

precipitation zone of the storm region as demarcated by a green line Fig. 10. Some of the model-simulated fields are also evaluated by considering their area averaged values over the $1^{\circ} \times 1^{\circ}$ grey box around NCR as drawn in Fig. 10. The region over and around $77.2^{\circ} \mathrm{E}$ and $28.6^{\circ} \mathrm{N}$ would be considered the NCR or the region of study/interest.

The analysis of the dynamical properties pertaining to the winter hailstorm along the axis demarcated in Fig. 10 is provided in Fig. 11. Model simulates a region of high equivalent potential temperature (EPT) over the NCR, as seen in the Fig. 11a. This represents higher temperatures and moisture content in the mid-troposphere, whereas in the lower troposphere decreased EPT is noticed. This represents the region of instability spanning the atmospheric column which is the cause of the storm. The instability in the mid-tropospheric level is caused by the WD depression as observed at $500 \mathrm{hPa}$. In this region, vertical wind (Fig. 11a) shows cells with updraft (positive values of vertical wind showing upward motion) and downdraft (negative values of vertical wind showing downward motion) conditions. Hailstorms forming processes are known for multiple cellular structure showing regions of updrafts and downdrafts within the cloud, with dynamic movement and reflectivity patterns. The updrafts originate from the air inflow from the surface towards the cloud in the opposite direction of storm movement (Chalon et al., 1976). Whereas, the downdraft cells are caused by the air that ascends in the updrafts, and ultimately flows as outflow of air towards the front and back of the storm movement (Fankhauser, 1976; Strauch and Merrem, 1976). Relative vorticity and divergence in Fig. 11b, show alternative cells of positive and negative relative vorticity over NCR, which correspond to cyclonic and anti-cyclonic circulation, respectively. These cells represent a gradient of vorticity, depicting a positive vorticity advection which culminates in rising air. Associated to these cells are regions of divergence and convergence. The convergence zone observed in the mid-tropospheric level corresponds to the multiple cells of the hailstorm. These define the movement of

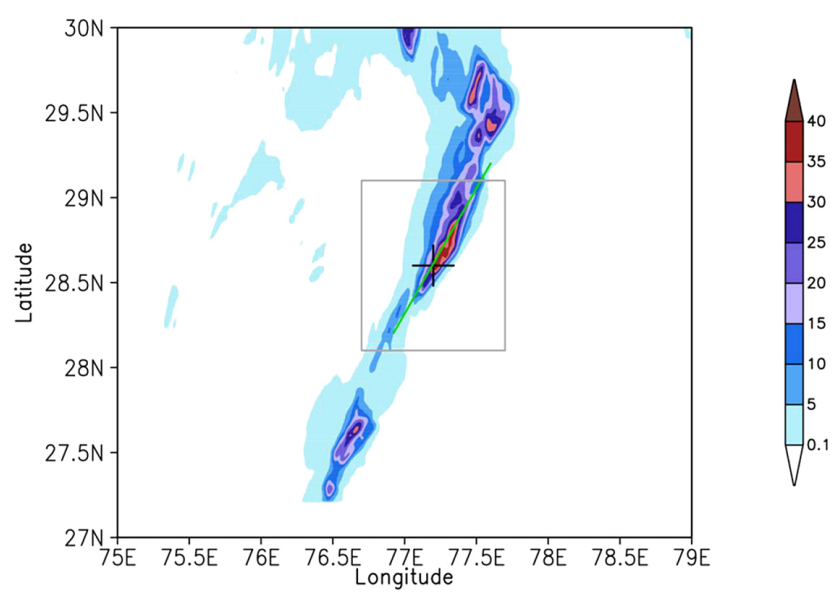

Figure 10. Model precipitation $(\mathrm{mm} / 0.5 \mathrm{~h})$ at 17:00 UTC $17 \mathrm{Jan}-$ uary 2013 at $1 \mathrm{~km}$ horizontal model resolution with hail option. Plus sign denotes NCR. (The green line drawn across the maximum precipitation zone, along which vertical cross sections of various variables are analyzed and $1^{\circ} \times 1^{\circ}$ grey box around NCR over which area averaged parameters are discussed in following sections.)

hydrometeors through the associated updrafts and downdrafts. As discussed above, the multiple cells formed in the clouds promote the formation of hailstones. Furthermore, positive specific humidity anomaly over NCR is observed in the mid-troposphere (Fig. 11c). This indicates that the atmospheric column over NCR up to $200 \mathrm{hPa}$ shows a high moisture zone. This increased level of moisture is required not only for growth of rain drops, but also for diffusional and accretional growth of the hailstones. With the evolution of the storm, there is increase in different hydrometeors as discussed above. This indicates increase in reflectivity during storm formation (Fig. 11c). The storm shows increase of RW droplets, which congregate in the lower levels of atmosphere, showing high reflectivity values in the same region. The positive reflectivity values do not extend beyond $600 \mathrm{hPa}$, showing that this winter hailstorm does not have the deep convection as observed in tropical summer thunderstorms. Therefore, the question of the cause of hailstorm formation during this storm still remains.

To understand the reason for development of the instability driving the winter hailstorm, the geopotential height over the region is studied (Fig. 11d). Over NCR, the geopotential height anomaly shows an increase around $400-200 \mathrm{hPa}$. This increase is associated with the dipping in the perturbation geopotential height contour lines. These changes are due to the tropopause fold penetrating the troposphere. The dip in the tropopause height values is also observed in the station data over New Delhi (Source: University of Wyoming, sounding data). This tropopause lowering is associated with baroclinic instability occurring over the region (Bush and Peltier, 1994). The increased storm intensity over the region is caused by the baroclinic instability due to the passing 

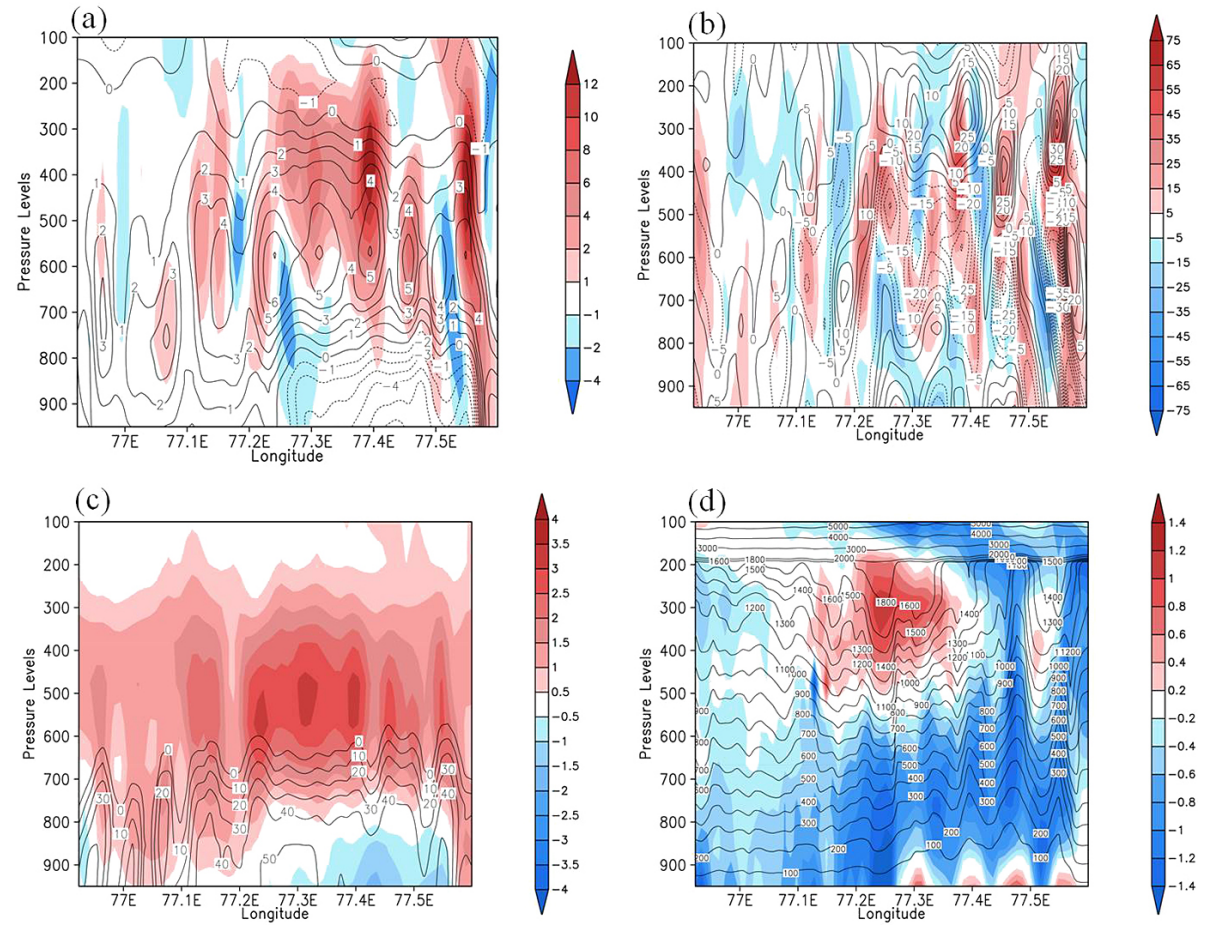

Figure 11. Longitude-pressure cross section (at the green line shown in Fig. 10) for model output with hail option at $1 \mathrm{~km}$ resolution at 17:00 UTC 17 January 2013 for (a) vertical wind ( $\mathrm{m} \mathrm{s}^{-1}$; shaded) and equivalent potential temperature $\left({ }^{\circ} \mathrm{C}\right.$; contour), (b) relative vorticity $\left(\times 10^{-4} \mathrm{~s}^{-1}\right.$; shaded) and divergence $\left(\times 10^{-4} \mathrm{~mm}\right.$; contour $)$, (c) specific humidity anomaly (shaded) and reflectivity (dBZ; contour) and (d) geopotential height anomaly (shaded) and perturbation geopotential height ( $\mathrm{m}$; contour).

WD and the development of cyclonic circulation. The midlatitude migratory WD attains higher intensities in form of a baroclinically unstable disturbance specifically over the Indian region (Rao and Rao, 1971; Singh and Agnihotri, 1977). This instability in the mid- to upper tropospheric levels generates the turbulent convective energy required for the development of updrafts during storm occurrence. With the availability of moisture in the atmospheric column, the instability leads to heavy precipitation. But a WD over northern India does not always lead to hail formation during winter. Hail precipitation in model simulation is seen from 16:00-17:00 UTC 17 January 2013 (Fig. 9). The updrafts driven by the instability developed over the region cycles the hail through the cloud. Hail particle successively moving through the vertical column grows in the upward motion and melts/sheds in the downward movement. With each cycle, the hailstone grows a new layer of ice forming the concentric circles seen in a hailstone cross section as discussed above. Thus, vertical wind velocity is an important factor for the hail formation. Heymsfield et al. (2005) describes that strong convective updrafts (with vertical wind speed greater than $5-10 \mathrm{~m} \mathrm{~s}^{-1}$ ) suppress homogenous nucleation to form ice particles which grow to form hail. Whereas, lower wind speeds would not attain enough energy to develop a strong hailstorm. The model-simulated vertical wind updraft speeds

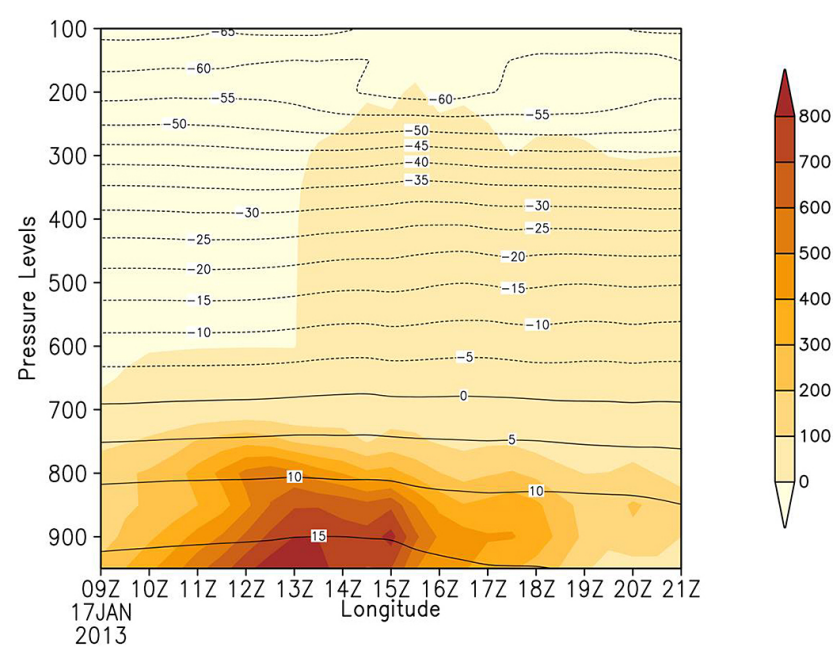

Figure 12. Time-pressure cross section (area averaged over the grey box shown in Fig. 10) at $1 \mathrm{~km}$ horizontal model resolution with hail option for CAPE $\left(\mathrm{J} \mathrm{kg}^{-1}\right.$; shaded $)$, temperature $\left({ }^{\circ} \mathrm{C}\right.$; black contours) and specific humidity ( $\mathrm{g} \mathrm{kg}^{-1}$; blue contours).

over NCR show a magnitude of 4-6 $\mathrm{m} \mathrm{s}^{-1}$ which provide sufficient time for ice particle growth by dry or wet growth.

The instability developed in the mid-tropospheric levels due to the WD develops propensity for baroclinic atmosphere 
(a) 42182 VIDD New Delhi

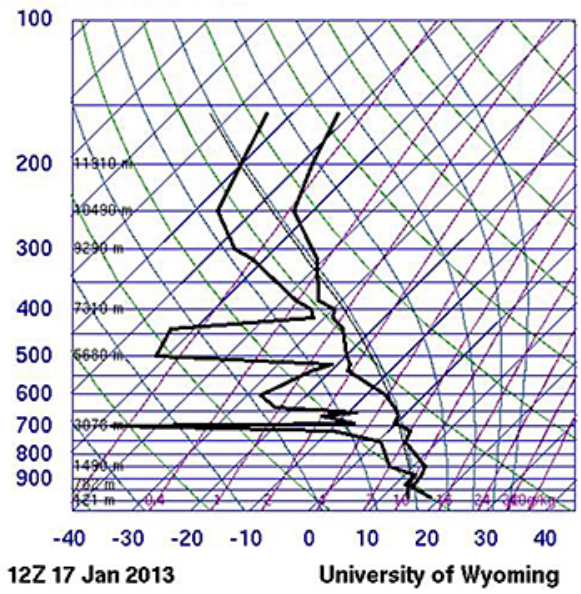

(b)

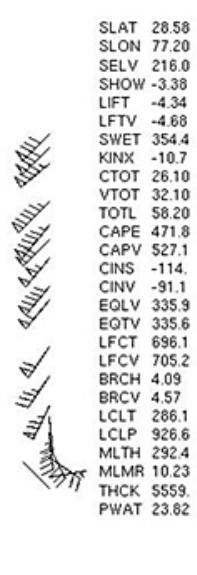

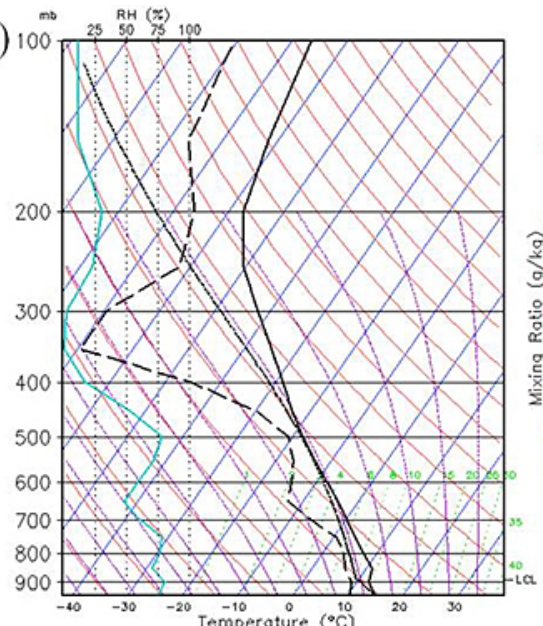

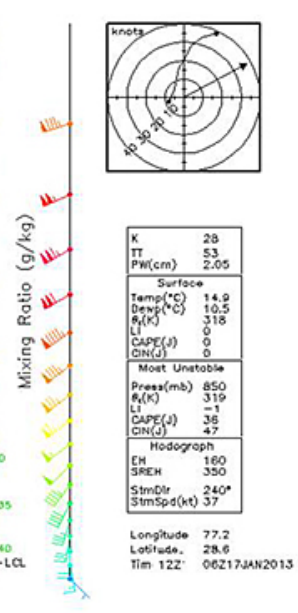

Figure 13. Sounding data at NCR at 12:00 UTC 17 January 2013 in graphical output for (a) observation and (b) 1 km horizontal model resolution with hail option.
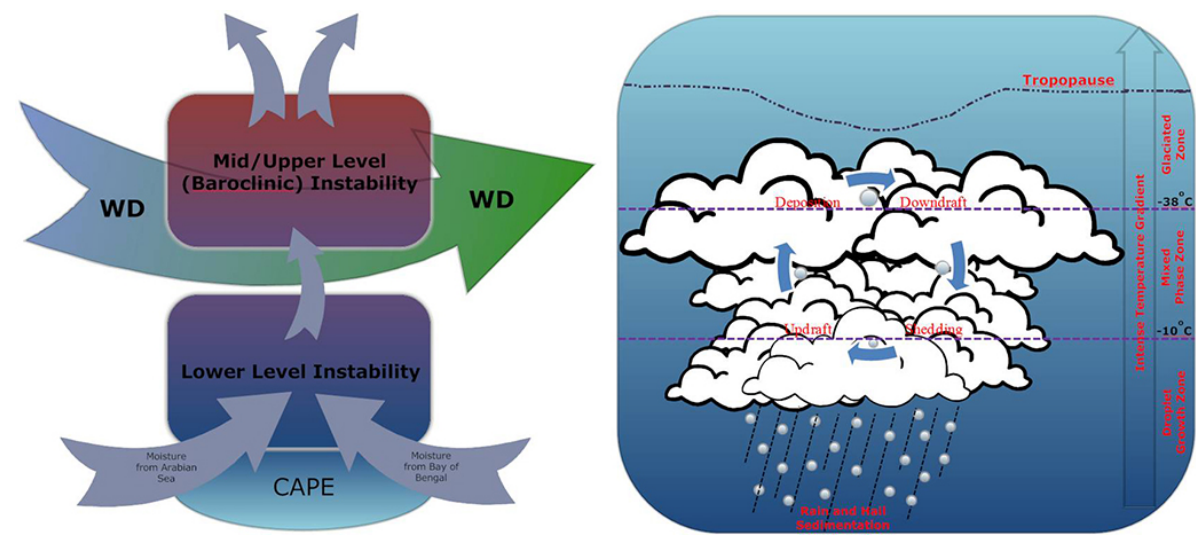

Figure 14. Conceptual model of the winter hailstorm.

in the upper half of troposphere. When the temporal variation of temperature profile of the region is analyzed, a dip is observed in the $-60^{\circ} \mathrm{C}$ isotherm around 16:00-17:00 UTC (Fig. 12). This lowering corresponds to the troposphere fold discussed before. The lowering of the tropopause causes incursion of colder stratospheric layers into the warmer troposphere. This in turn causes development of a steep temperature gradient as seen in the figure, which enhances upper level instability. Still the reasons for instability in the lower layers are yet not clearly discussed. To understand the lower layer instability, temporal variation in area averaged convective available potential energy (CAPE) and specific humidity are represented in black and blue contours of Fig. 12, respectively. In this figure, an increase of moisture over NCR in the lower levels of atmospheric column is observed along with development of CAPE from around 13:00 UTC. The source of this low level moisture incursion is majorly from the Arabian Sea and on a lesser extent from the Bay of Bengal (Fig. 5). The moisture convergence develops buoyancy which enhances the propensity of increase of CAPE in the atmospheric column. There is reduction in CAPE values in subsequent time periods after 13:00 UTC. The increase of CAPE defines the potential energy that is available to drive a storm and release of CAPE in form of kinetic energy promotes storm development. Along with this the low level moisture incursion provides the buoyancy required for the air parcel to rise. Thus, upper level instability is predominantly by the existing WD embedded with the low level instability due to moisture incursion and development of CAPE lead to instability spanning the troposphere which makes it conducive conditions for hailstorm formation. Muller et al. (2010) and Rosenfeld and Lensky (1998) described the "continental" clouds having three zones in the vertical direction based on temperature variation: diffusional droplet growth zone (up to $\left.-10^{\circ} \mathrm{C}\right)$, mixed-phase zone $\left(-10\right.$ to $\left.-38^{\circ} \mathrm{C}\right)$ and glaciated zone (above $-38^{\circ} \mathrm{C}$ ). The isotherm of $-38^{\circ} \mathrm{C}$ is termed as homogeneous freezing isotherm beyond which homogenous nucleation occurs. As per Fig. 12, it can be concluded that the 
mixed-phase zone for the current hailstorm can be considered within $600-350 \mathrm{hPa}$. The mixed-phase zone is the region for development of hail particles due to growth by deposition of water particles. This zone in the model-simulated output coincides with the region having strong convergence influence and higher specific humidity, promoting hail formation along with raindrop growth. The region of glaciation in the upper levels of troposphere is imperative for the development of small ice particles through homogenous nucleation. These particles further grow to form the various ice precipitation forms; in this case, the form of precipitation is hail. The problem with winter storms is that instability is not sufficient enough for the cloud to extend to this height or form an anvil. But in the 17 January 2013 hailstorm, the instability extending from low to upper levels of troposphere discussed above allows the formation of ice nuclei in the glaciations zone leading to winter hail formation.

The clarity of two different zones of instability can be described in the sounding data of NCR for 17 January 2013. Figure 13 represents the model and observed sounding data in a graphical format. The development of instability at 12:00 UTC is an indicator for the storm development. This instability is measured by the gap between the air parcel lapse rate and environmental lapse rate. There is increased instability around mid-tropospheric level in both model and observation due to the approaching WD and development of baroclinic instability. Another region of higher instability seen in the observation is around $700 \mathrm{hPa}$, which is underestimated in the model simulation. This region of instability corresponding to the lower level convection is described due to development of CAPE and the moisture incursion. There is augmented moisture content in the atmospheric column as seen in the relative humidity profile provides buoyancy to the air parcel. Combination of low level available potential energy and moisture incursion, along with upper level baroclinic instability due to the presence of WD, led to sufficient instability for winter hail formation.

\section{Conclusions}

This study investigates the cause of hailstorm during winter over NCR. Winter months of December-January-February, specifically over northern India, are considered a cold and dry season. But high surface temperature and supplementary moisture availability are the prerequisite for hailstorm development. And winter storms are not able to attain the intensity and depth of a convective storm. Thus, the question of hail being formed during the winter season is fascinating due to its uniqueness.

The comprehensive analysis of the results has led the authors to describe the mechanism of the winter hailstorm formation over NCR. These conclusions have been summarized in the form of an illustration or conceptual model as given in Fig. 14. On the day of the hailstorm, 17 January 2013, high moisture availability is seen over NCR. The Arabian Sea and the Bay of Bengal are identified as the sources of this moisture in-flow. This moisture incursion along with the release of CAPE in the lower levels leads to development of the lower level instability. However, this instability is not sufficient for a winter storm. On the other hand winter precipitation is experienced over northern India due to WDs. These migratory disturbances in the sub-tropical westerly jet cause baroclinic instability in the mid/upper troposphere. Thus, with two different sources of instability this winter storm is able attain conditions similar to deep convective storms favorable for hail formation.

The lower level instability formed due to release of kinetic energy and buoyancy of air parcel due to high relative humidity. This mid/upper level instability develops due to lowering of the tropopause which intensifies the temperature gradient. Thus, a rising air parcel gets an enhanced push to continue rising, which denotes the formation clouds having larger vertical extents. Ice nucleation, which develops hail nuclei, is enhanced in such clouds as they attain the glaciated zone. These clouds are also associated with cells having turbulent upward and downward wind movement. Development of these conditions supports cycling of hail through the clouds and promotes its formation through shedding, deposition and other hail processes. As the hailstones grow, they ultimately sediment or precipitate out to cause the hailstorm during winter.

Author contributions. A. Chevuturi, A. P. Dimri and U. B. Gunturu defined objectives and designed the experiment. A. Chevuturi carried out the simulation and prepared the results. A. P. Dimri and U. B. Gunturu were instrumental in analysis of the results and outlining the discussion. A. Chevuturi prepared the manuscript with contributions from all co-authors.

Acknowledgements. This work is partially funded by the senior research fellowship provided to A. Chevuturi by Human Resource Development Group at Council for Scientific and Industrial Research, India. Authors would like to acknowledge the use of NCEP FNL data set as the initial and boundary conditions as input for the model simulation archived at Research Data Archive at the National Center for Atmospheric Research, Computational and Information Systems Laboratory. Authors acknowledge the Global Modeling and Assimilation Office (GMAO) and the GES DISC for the dissemination of MERRA data set. Authors like to acknowledge GSFC/DAAC, NASA for the access of TRMM data. Interpolated OLR data used in the study is provided by the NOAA/OAR/ESRL PSD, Boulder, Colorado, USA.

Edited by: M.-C. Llasat

Reviewed by: two anonymous referees 


\section{References}

Attri, S. D. and Tyagi, A.: Climate Profile of India, Meteorological Monograph No. Environment Meteorology-01/2010, India Meteorological Department, New Delhi, India, available at:http: //www.imd.gov.in/doc/climate_profile.pdf (last access: 17 March 2013), 2010

Bush, A. B. G. and Peltier, W. R.: Tropopause Folds and SynopticScale Baroclinic Wave Life Cycles, J. Atmos. Sci., 51, 15811604, 1994.

Chalon, J. P., Famkhauser, J. C., and Eccles, P. J.: Structure of an Evolving Hailstorm, Part 1: General Characteristics and Cellular Structure, Mon. Weather Rev., 104, 564-575, 1976.

Chatterjee, P., Pradhan, D., and De, U. K.: Simulation of hailstorm event using Mesoscale Model MM5 with modified cloud microphysics scheme, Ann. Geophys., 26, 3545-3555, 2008, http://www.ann-geophys.net/26/3545/2008/.

De, U. S., Dube, R. K., and Rao, G. P.: Extreme weather events over India in the last 100 years, J. Ind. Geophys. Union, 9, 173-187, 2005.

Dimri, A. P.: Impact of horizontal model resolution and orography on the simulation of a western disturbance and its associated precipitation, Meteorol. Appl., 11, 115-127, 2004.

Dimri, A. P. and Chevuturi, A.: Model sensitivity analysis study for western disturbances over the Himalayas, Meteorol. Atmos. Physics, 123, 155-180, 2014

Fankhauser, J. C.: Structure of an Evolving Hailstorm, Part II: Thermodynamic Structure and Airflow in the Near Environment, Mon. Weather Rev., 104, 576-587, 1976.

Fiori, E., Parodi, A., and Siccardi, F.: Turbulence closure parameterization and grid spacing effects in simulated supercell storms, J. Atm. Sci., 67, 3870-3890, 2010.

Gomes, J. L. and Chou, S. C.: Dependence of partitioning of model implicit and explicit precipitation on horizontal resolution, Meteorol. Atmos. Phys., 106, 1-18, 2010.

Heymsfield, A. J., Miloshevich, L. M., Schmitt, C., Bansemer, A., Twohy, C., Poellot, M. R., Fridlind, A., and Gerber, H.: Homogeneous ice nucleation in subtropical and tropical convection and its influence on cirrus anvil microphysics, J. Atmos. Sci., 62, 4164, 2005.

Houze Jr., R. A.: Structures of atmospheric precipitation systems A global survey, Radio Sci., 16, 671-689, 1981.

Howarth, D. A.: Seasonal variations in the vertically integrated water vapor transport fields over the Southern Hemisphere, Mon. Weather Rev., 111, 1259-1272, 1983.

Huffman, G. J., Adler, R. F., Bolvin, D. T., Gu, G., Nelkin, E. J., Bowman, K. P., Hong, Y., Stocker, E. F., and Wolff, D. B.: The TRMM Multi-satellite Precipitation Analysis: Quasi-Global, Multi-Year, Combined-Sensor Precipitation Estimates at Fine Scale, J. Hydrometeorol., 8, 38-55, 2007.

Koteswaram, P.: The Asian summer monsoon and the general circulation over tropics, The proceeding of the International symposium on Monsoons of the World, New Delhi, India, 105-110, 1958.

Lau, W. K., Waliser, D. E., and Goswami, B. N.: South Asian monsoon, in: Intraseasonal variability in the atmosphere-ocean climate system, Springer, Berlin Heidelberg, Germany, 21-72, 2012.
Liebmann, B. and Smith, C. A.: Description of a Complete (Interpolated) Outgoing Longwave Radiation Dataset, Bull. Am. Meteorol. Soc., 77, 1275-1277, 1996.

Lin, Y. L., Farley, R. D., and Orville, H. D.: Bulk Parameterization of the Snow Field in a Cloud Model, J. Climate Appl. Meteorol., 22, 1065-1092, 1983.

Muller, C. L., Kidd, C., Fairchild, I. J., and Baker, A.: Investigation into clouds and precipitation over an urban area using micro rain radars, satellite remote sensing and fluorescence spectrophotometry, Atmos. Res., 96, 241-255, 2010.

National Centers for Environmental Prediction/National Weather Service/National Oceanic and Atmospheric Administration/US Department of Commerce: NCEP FNL Operational Model Global Tropospheric Analyses, continuing from July 1999, Research Data Archive at the National Center for Atmospheric Research, Computational and Information Systems Laboratory, available at: http://rda.ucar.edu/datasets/ds083.2 (last access: 5 May 2013), 2000.

NNDC-CDO: NOAA National Data Center Climate Data Online, http://www7.ncdc.noaa.gov/CDO/cdo, last access: 5 May 2013.

Orville, H. D. and Kopp, F. J.: Numerical Simulation of the Life History of a Hailstorm, J. Atmos. Sci., 34, 1596-1618, 1977.

Pruppacher, H. R. and Klett, J. D.: Microphysics of clouds and precipitation, 2nd edition, Atmos. Ocean. Sci. Lib., 18, Springer, New York, USA, 976 pp., 2010.

Puranik, D. M. and Karekar, R. N.: Western disturbances seen with AMSU-B and infrared sensors, J. Earth Syst. Sci., 118, 27-39, 2009.

Ramage, C. S.: Monsoon Meteorology, Int. Geophys. Academic Press, San Diego, USA, Ser. 15, 1971.

Rao, V. B., and Rao, S. T.: A theoretical and synoptic study of western disturbances, Pure. Appl. Geophys., 90, 193-208, 1971.

Rienecker, M. M., Suarez, M. J., Gelaro, R., Todling, R., Bacmeister, J., Liu, E., Bosilovich, M. G., Schubert, S. D., Takacs, L., Kim, G. K., Bloom, S., Chen, J., Collins, D., Conaty, A., da Silva, A., Gu, W., Joiner, J., Koster, R. D., Lucchesi, R., Molod, A., Owens, T., Pawson, S., Pegion, P., Redder, C. R., Reichle, R., Robertson, F. R., Ruddick, A. G., Sienkiewicz, M., and Woollen, J.: MERRA: NASA's modern-era retrospective analysis for research and applications, J. Climate, 24, 3624-3648, 2011.

Rosenfeld, D. and Lensky, I. M.: Satellite-based insights into precipitation formation processes in continental and maritime convective clouds, B. Am. Meteorol. Soc., 79, 2457-2476, 1998.

Rutledge, S. A. and Hobbs, P. V.: The mesoscale and microscale structure and organization of clouds and precipitation in extratropical cyclones. XII: A numerical study of precipitation processes in narrow cold-frontal rainbands, J. Atmos. Sci., 41, 2949 2972, 1984.

Sikka, D. R.: Some aspects of the life history, structure and movement of monsoon depressions, PAGEOPH, 115, 1501-1529, 1977.

Simpson, J. and Tao, W. K.: The Goddard Cumulus Ensemble Model. Part II: Applications for studying cloud precipitating processes and for NASA TRMM, Terrestrial, Atmospheric and Oceanic Sciences, 4, 73-116, 1993.

Singh, M. S. and Agnihotri, C. L.: Baroclinity over India in winter and its relation to western disturbances and jet streams - Part 1, Ind. J. Meterol. Hydrol. Geophys., 28, 303-310, 1977. 
Skamarock, W. C., Klemp, J. B., Dudhia, J., Gill, D. O., Barker, D. M., Duda, M. G., Huang, X., Wang, W., and Powers, J. G.: A Description of the Advanced Research WRF Version 3, MMM, UCAR, available at: http://www.mmm.ucar.edu/wrf/users/docs/ arw_v3.pdf (last access: 17 August 2012), 2008.

Strauch, R. G. and Merrem, F. H.: Structure of an Evolving Hailstorm, Part III: Internal Structure from Doppler Radar, Mon. Weather Rev., 104, 588-595, 1976.

Tao, W. K., and Simpson, J.: The Goddard Cumulus Ensemble Model. Part I: Model description, Terrestrial, Atmospheric and Oceanic Sciences, 4, 35-72, 1993.
Wang, W., Barker, D. M., Bruy'ere, C., Duda, M. G., Dudhia, J., Gill, D. O., Michalakes, J., and Rizvi S.: WRF Version 3 Modeling System User's Guide, MMM, UCAR, available at: http: //www.mmm.ucar.edu/wrf/users/docs/user_guide_V3.0 (last access: 15 August 2012), 2010.

Wisner, C., Orville, H. D., and Myers C.: A numerical model of a hail-bearing cloud, J. Atmos. Sci., 29, 116-1181, 1972.

Xie, P. and Arkin P. A.: Global monthly precipitation estimates from satellite-observed outgoing longwave radiation, J. Climate, 11, 137-164, 1998. 